\title{
Determinants of Flooding in Port Harcourt Metropolis, Nigeria
}

\author{
Akukwe Thecla I.
}

\begin{abstract}
Flood is a natural phenomenon but human activities and interventions such as uncontrolled urbanization coupled with increased population have increased the damages and losses caused by floods. Urbanization aggravates flooding by limiting where run-off can flow and the increased impervious layers in urban areas obstruct the natural channel thereby shortening the time taken by flood water to flow into river. This study focused on analyzing the determinants of flooding in Port Harcourt metropolis, Nigeria and it revealed nine factors as being responsible for flooding in the study area. Simple percentages were used to analysed these nine factors; absence of/inadequate drainage facilities and heavy rainfall were ranked the first and second $(15.74 \%$ and $15.59 \%)$ respectively. Further classification of these causes of flooding into meteorological factors, topographical factors, human factors and others, shows that human factors represents more than 2/3 of the total identified causes of flooding. Principal Component Analysis (PCA) was carried out and the nine factors responsible for flooding in the study area were reduced to four underlying dimensions (viz. heavy rainfall, unplanned urban development, poor drainage quality and low-lying topography) which explain $83.20 \%$ of the total variance in causes of flooding in the metropolis. Recommendations such as implementation of the Greater Port Harcourt City Development Master Plan; instilling communal actions; demolition of illegal structures; sustainable drainage systems etc were made to curtail the perennial flooding that occur in the study area.
\end{abstract}

Keywords: Flooding, Nigeria, Port Harcourt, Urbanization

\section{Introduction}

Throughout history, water supply has been among the decisive factors in the search for adequate settlement locations. This has made river banks, coastal areas and lakesides to become preferred living spaces (WMO/GWP, 2008). Most cities, including Port-Harcourt are located in the valleys and flood plains or on coasts owing to their additional location advantages which favour development. Flood plains in the lower reaches of rivers provide fertile and flat land for productive agriculture. Moreover, estuaries and other coastal areas are more favoured as settlement locations since they may serve as linkages between river and sea navigation (WMO/GWP, 2008). However, one of the costs of such favourable locations is an increased flood risk. Irrespective of this, people continue to live in these areas.

A flood is the accumulation of too much water which rises to overflow land which is not normally submerged (Mukhopadhyay, 2010). Flooding can comprise overflow of a river as a result of prolonged seasonal rainfall, rainstorm, snowmelt, dam-breaks, accumulation of rainwater in low-lying areas with a high water table, or inadequate storm drainage. Floods could also be caused by intrusion of sea water onto coast lands during cyclonic/tidal surges (Handmer, Penning-Rowsell and Tapsell, 1999; Stoltman, Lidstone and DeChano, 2004). Floods have been noted to cause about one third of all deaths, one third of all injuries and one third of all damage from natural disasters (Askew, 1999). Flooding in various parts of Nigeria have forced thousands of people away from their homes, destroyed businesses, polluted water resources and increased the risk of diseases (Jeb and Aggarwal, 2008; Etuonovbe, 2011; Olorunfemi, 2011).

The occurrence of floods in Nigeria is not a recent phenomenon (Ayoade, 1979; Ayoade and Akintola, 1980; Olaniran, 1983; Ologunorisa and Terso, 2006; Adeloye and Rustum, 2011). The recent occurrences of flooding in Nigeria such as Sokoto flood in 2010, Ibadan flood in 2011, Lagos flood in 2011, and most parts of the country in 2012 had shown that flooding is one of the major environmental problems faced in Nigeria. Floods in Nigeria occur in three main forms, viz; coastal flooding, river flooding and urban flooding (Oriola, 1994; Okoduwa, 1999; Folorunsho and Awosika 2001; Ologunorisa, 2004; Orok, 2011). A review of these forms of floods have shown that, no single factor can be singled out as the only factor responsible for each flood type, though, a factor (e.g. rainfall) can cause all flood types. It has increasingly been acknowledged that the Niger Delta region in Nigeria experiences perennial floods owing to its location, low-lying topography and heavy rainfall, and Port Harcourt (located in the Niger Delta region) is one of such areas considered to be vulnerable to flooding. Some research works that examined the causal factors of flooding in Nigeria have attributed it to topography, soil/vegetation/river alteration, increased heavy rainfall, uncontrolled waste dumping, land use change and unplanned urbanisation (Oriola, 1994; Onokerhoraye, 1995; Parker, 1999; Folorunsho and Awosika 2001; Ologunorisa, 2004; Ogba and Utang, 2008; Adeloye and Rustum, 2011). 
Identification of these causes of flooding gives an insight to finding solution to the problem of flooding. This study therefore sought to analyse and classify the determinants of flooding in Port Harcourt metropolis, and make recommendations on ways to curtail the perennial flooding that occur in the metropolis based on the identified causes.

\subsection{The Study Area}

\subsubsection{Location}

Port Harcourt metropolis is located between Latitude $4^{0} 45^{\prime} \mathrm{N}$ and Latitude $4^{0} 55^{\prime} \mathrm{N}$, and Longitude $6^{0} 55^{\prime} \mathrm{E}$ and Longitude $7^{0} 05^{\prime} \mathrm{E}$. The city lies at the mouth of River Bonny in Rivers State. It is located at about $25 \mathrm{~km}$ from the Atlantic Ocean and it is situated between the Dockyard creek/Bonny River and the Amadi creek. It lies at an average altitude of about $12 \mathrm{~m}$ above mean sea level. Port Harcourt metropolis as our study area spans over two Local Government Areas (LGAs) viz; Port Harcourt and Obio/Akpor (Fig. 1) and was further divided into 13 Zones (Fig. 2).

\section{FIG.1: Map of Port Harcourt Metropolis}

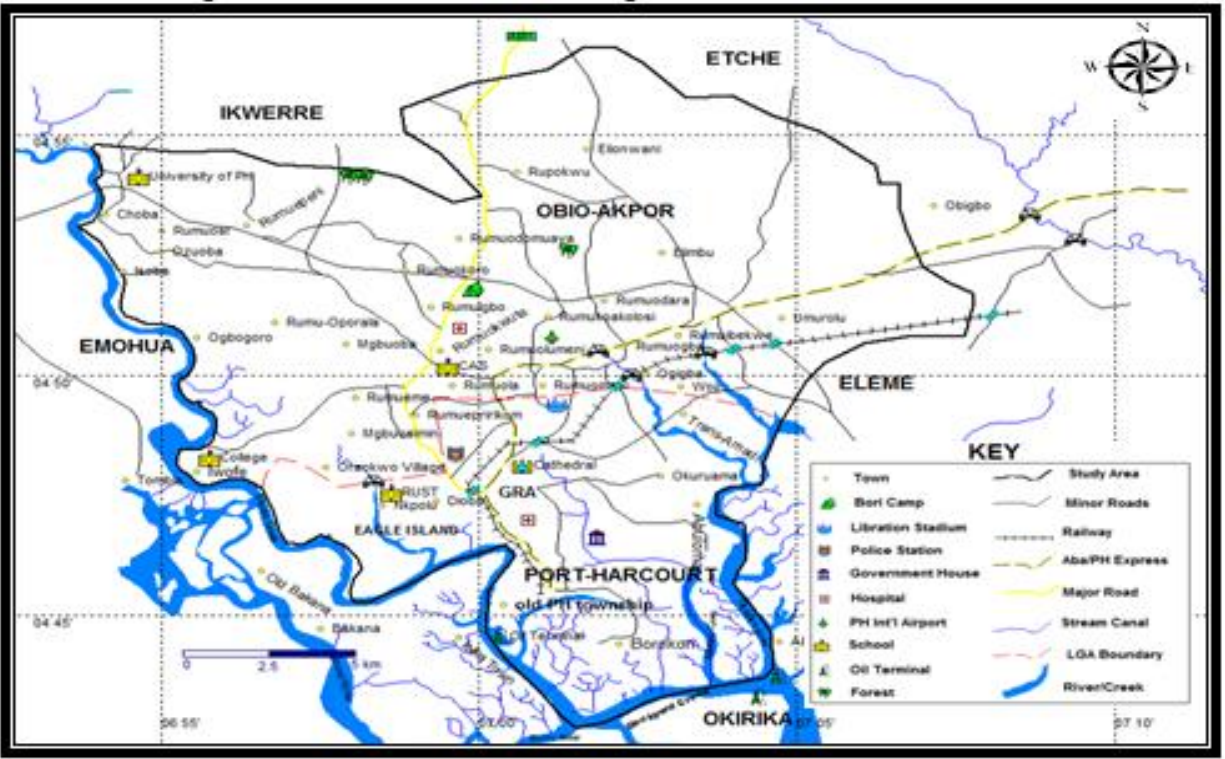

Source: Adapted from Google Earth

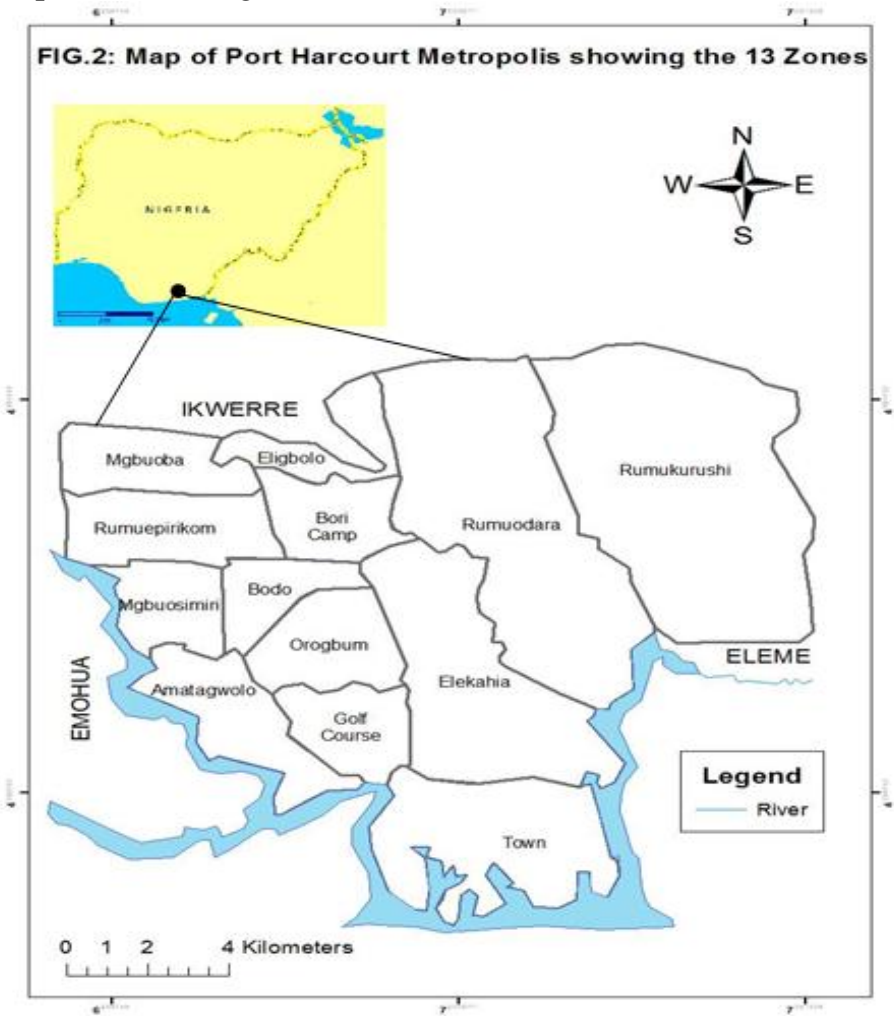

Source: Survey Department Port Harcourt, 1999 


\subsubsection{Climate}

The study area lies within the Koppen Tropical Rainy Af climatic zone of the Koppen classification (Koppen, 1936). Here, the average temperature for every month is above $18^{\circ} \mathrm{C}$ and there is adequate moisture in virtually all the months. Port Harcourt metropolis experiences two seasons viz; dry and rainy seasons. Temperatures over Port Harcourt metropolis are constantly high with a mean maximum of about $34^{\circ} \mathrm{C}$ and a mean minimum of about $21^{\circ} \mathrm{C}$. The highest temperatures are recorded between the months of April and October.

\subsubsection{Population}

The 1991 National Population Census results showed that Port Harcourt metropolis comprising Port Harcourt and Obio/Akpor LGAs had a population of 703,416 persons (Akpoghomeh, 2001). In 2006, the population of Port Harcourt Metropolis grew to 1,000,908 persons (National Population Commission, 2006).

\subsection{Research Methodology}

Field survey, questionnaire and interviews were employed to achieve the objective of this research. According to Yamane (1967) and Israel (1992), the sampling size of population more than 100,000 persons is 400 using the equation below at $+/-5 \%$ level of precision;

$\mathrm{n}=\mathrm{N} / 1+\mathrm{N}\left(\mathrm{e}^{2}\right)$.

where;

$\mathrm{n}-$ is the sample size

$\mathrm{N}$ - is the population i.e. census population figure

$\mathrm{e}-$ is the level of precision/sampling error

A total of 650 copies (though these exceeded the benchmark of 400 persons since the population of Port Harcourt metropolis is over 1,000,000 persons) of questionnaire were purposively distributed; 50 for each zone for equal and unbiased representation, using the simple random sampling techniques. The simple random sampling procedure which ensures that every respondent in each zone has a known and equal chance (i.e. equiprobability) of being administered a questionnaire was adopted in administering the copies of questionnaire, because once a respondent was chosen he/she could not be chosen again. Six hundred and thirteen (613) copies of the distributed copies questionnaire were retrieved. The total number of responses exceeded 613 because respondents selected either one or more factors as being the causes of flooding in their various zones. Simple percentages $(\%)$ were used to analyse and classify the factors responsible for flooding in Port Harcourt Metropolis. Principal Component Analysis (PCA) was used to extract the components and determine the underlying dimensions of the causal factors of flooding in Port Harcourt metropolis.

\section{Results and Discussion}

\subsection{Factors Responsible for Flooding in Port Harcourt Metropolis}

The causes of flooding in Port Harcourt metropolis were identified based on observation, interviews and review of literatures. Table 1 below shows the identified causes of flooding in Port Harcourt metropolis. These causes range from a combination of meteorological (climatologically) and hydrological extremes which are further aggravated by topographical and human factors. A factor (e.g. heavy rainfall) could cause all flood types, but, could not be the only factor responsible for these flood types.

TABLE 1: Respondents' identified causes of flooding in Port Harcourt metropolis

\begin{tabular}{|l|l|l|c|}
\hline Cause of flooding & No. of Responses & Percentage (\%) & Rank \\
\hline Absence of/ inadequate drainage facilities & 102 & 15.74 & 1 \\
\hline Heavy rainfall & 101 & 15.59 & 2 \\
\hline Blocked drainage systems & 97 & 14.97 & 3 \\
\hline Impervious surfaces & 93 & 14.35 & 4 \\
\hline Inappropriate town planning/ uncontrolled urbanization & 79 & 12.19 & 5 \\
\hline Poor drainage network & 77 & 11.88 & 6 \\
\hline Flat terrain & 46 & 7.10 & 7 \\
\hline Climate change & 29 & 4.48 & 8 \\
\hline Unplanned development on flood plains & 24 & 3.70 & 9 \\
\hline Total & 648 & 100.00 & 9 \\
\hline
\end{tabular}

Source: Field work, 2011

\subsubsection{Absence/Inadequate drainage facilities}

The ranking of the causes of flooding in Port Harcourt shows that absence of/inadequate drainage facilities is considered the major cause of flooding as the majority (15.74\%) of the respondents indicated this (Table 1). Storm water drainage system is made up of gutters, manholes, curb inlets, roadsides culverts etc which aid to carry storm water to natural drains or rivers or other nearest water bodies. Flash floods have been encouraged in Port Harcourt metropolis due to the absence (where roads were constructed without provision made for local drainage system) or inadequacy of these drainage facilities. In some cases, where drainage 
facilities are present, they are either not large enough or insufficient to accommodate the excess run-off or not properly sloped (Plate1). The reason is that the drainage facilities would have been adequate when designed and because of rapid urbanization which increases surface run-off, their carrying capacities have turned out to be inadequate.

Also, economic development has taken place in virtually all areas of Port Harcourt metropolis intercepting with natural pathways of storm water. This has caused surface water to be trapped in some lowlying areas where there are no drains to convey surface run-off to natural drains. This is evident in most slums and unplanned settlements which have no drainage facilities e.g. along Alcon Road (Woji/Akpajo/Elelenwo Road). Also in Igbo Etche Road, off Eleme junction (Rumukwurushi Zone) flash and pondage floods occur as a result of this factor.

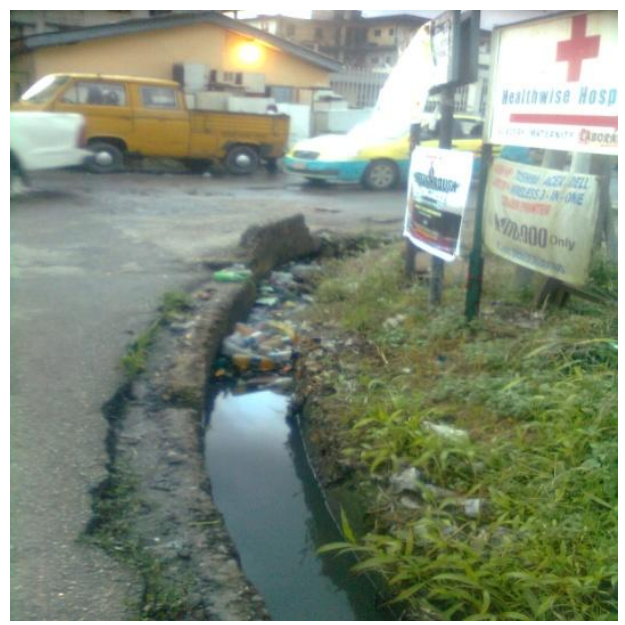

PLATE 1: Gutter not large enough to convey the excess run-off generated in Sagana Diobu, off Ikwerre Road behind Mile 1 Market in Town Zone. Note the solid wastes that have blocked the gutter.

\subsubsection{Heavy Rainfall}

From Table 1 above, $15.59 \%$ of the respondents attributed floods occurrence in Port Harcourt metropolis to heavy rainfall and it was ranked second as a cause of flooding in the study area. With an Af type of climate and its proximity to the Atlantic ocean, Port Harcourt Metropolis records an annual rainfall of above $2000 \mathrm{~mm}$ (see Fig.3) with not less than nine months of rainfall. Increased rainfall and/or prolonged rainfall is the major and direct cause of flash flood in Port Harcourt metropolis, other factors only aggravate all the flood types. It occurs as precipitation proceeds at a rate that exceeds infiltration and surface evacuation by drainage facilities.

FIG.3: Daily, Monthly and Annual Rainfall in Port Harcourt (1971-2007)

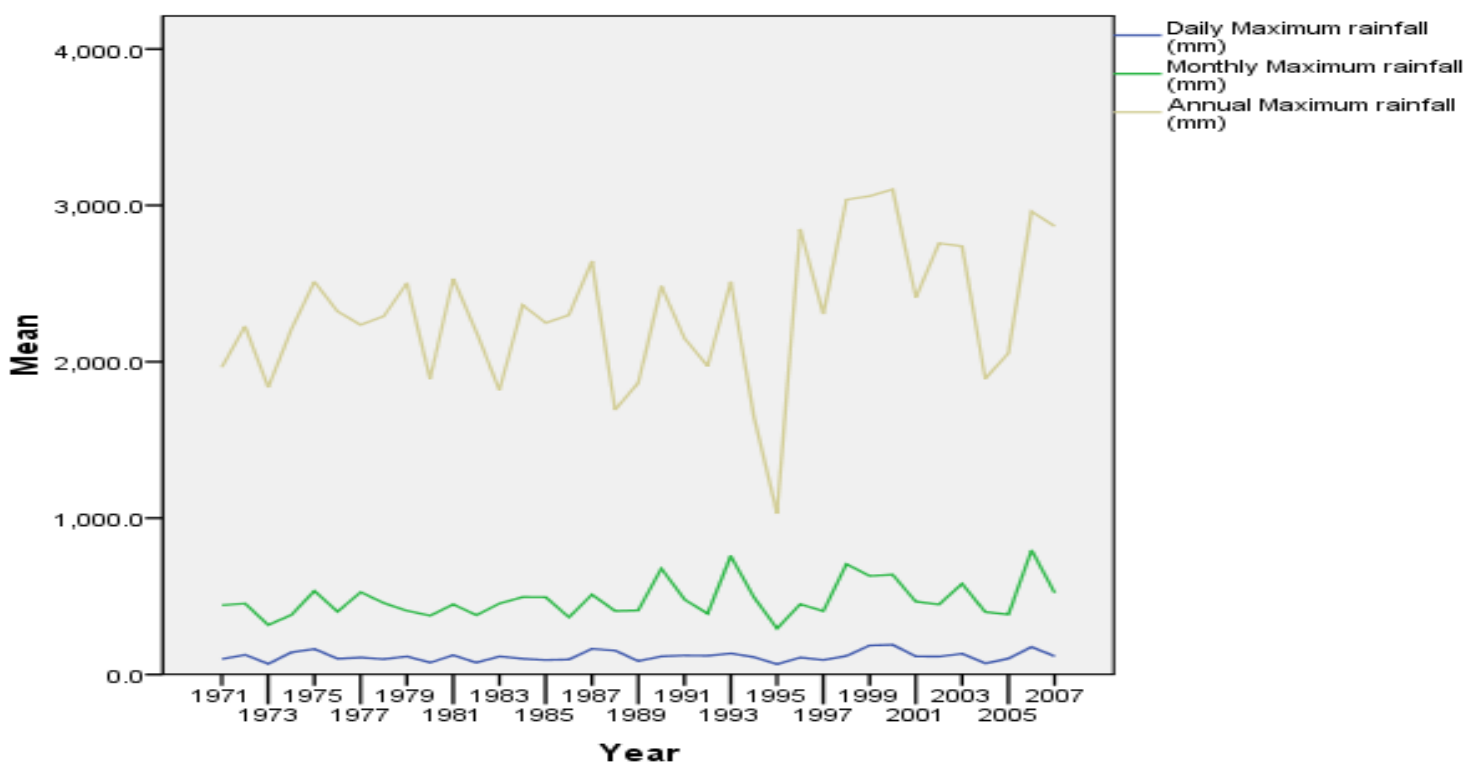




\subsubsection{Blocked Drainage systems}

This factor was ranked third as the major cause of flooding in Port Harcourt metropolis, and14.97\% of the respondents indicated this (Table 1). Where drainage facilities are available, some have been blocked by the introduction of wastes and debris. These blocked drainage facilities increase surface run-off by reducing the drainage capacities to carry storm water. For example, in old GRA (Golf course zone), most drains have been blocked and whenever it rains heavily, the entire area is flooded. This has been aggravated by inadequate clearing and maintenance of the drainage channels when the wastes might have been cleared out by statutory authorities. These blocked drainage facilities aggravate river flooding by increasing the rate at which floodwaters reach rivers and streams exceeding the natural capacities of these rivers and creeks. Though, blocked drainage facilities are found in all the Zones their effects on river flooding is felt by those who reside close to a major water body like body like in Town, Amatagwolo, Rumuepirikom, and Mgbuosimiri Zones.

\subsubsection{Impervious surfaces}

Impervious surfaces as a cause of flooding was ranked fourth and $14.35 \%$ respondents mentioned this (Table 1). Impervious surfaces are direct result of urbanization which have brought about change in land-use and built-up environments which reduce infiltration and percolation. The resultant effect is increased surface run-off which is generated faster than they are evacuated. Impervious surfaces exacerbate river flooding by increasing the rate at which storm water reach natural drains and making these floodwaters to reach rivers at the same time. Impervious surfaces just like increased rainfall, is responsible for river flooding in all the Zones where it is experienced. Flash flood and flood pondage also occur in Port Harcourt metropolis due to the fact that the designed capacities of available drainage facilities which were constructed years ago cannot cope with the increased volume of surface run-off generated presently as a result of impervious surfaces.

\subsubsection{Uncontrolled Urbanization/Inappropriate Town Planning}

From Table 1 above, this factor was ranked fifth as a major cause of flooding in the study area with $12.19 \%$ of the respondents indicating it. Due to quest for living spaces in Port Harcourt metropolis, trees have been cut down indiscriminately and houses built. Uncontrolled urbanization, cementation/pavement of surface soils, insufficient drainage systems, blocked drainage facilities etc, flood disasters have been intensified. Floods have been regarded as man-made disaster in Port Harcourt metropolis because residents have subjected themselves to flood risk by practices such as building houses in flood paths and floodable areas, constructing roads without drainage systems, blocking available drainage facilities with wastes etc. This unplanned urbanization has brought about changes in land-use which has reduced infiltration and increased surface run-off as houses and shops are constructed on natural water channels.

Economic development and inappropriate town planning have led to an explosion of poorly planned construction that has caused perennial flooding in Port Harcourt especially in areas like NTA/Choba Road, Mgbuoba Zone that appears to be the worst affected. However, built environments like Port Harcourt metropolis generate higher surface runoff because of decreased rates of infiltration and percolation (because of impervious surfaces) especially during periods of excessive heavy and or prolonged rainfall causing flash floods. Changes in the built-up areas restricts where floodwaters can go e.g. covering large parts of the ground with roofs, roads, and pavements, obstructing natural channels and building drains ensure that water moves to rivers more rapidly than it would under natural conditions. This had increase the volume of water reaching the rivers at a point in time as the rivers capacities are exceeded, thereby causing them to overflow their banks and flooding the adjoining areas (Woji River that overflows its bank to flood Woji/Slaughter road area). Uncontrolled urbanization has therefore led to inadequate provision of drainage facilities which induces flood pondage and this is common in all the zones (Plate2).

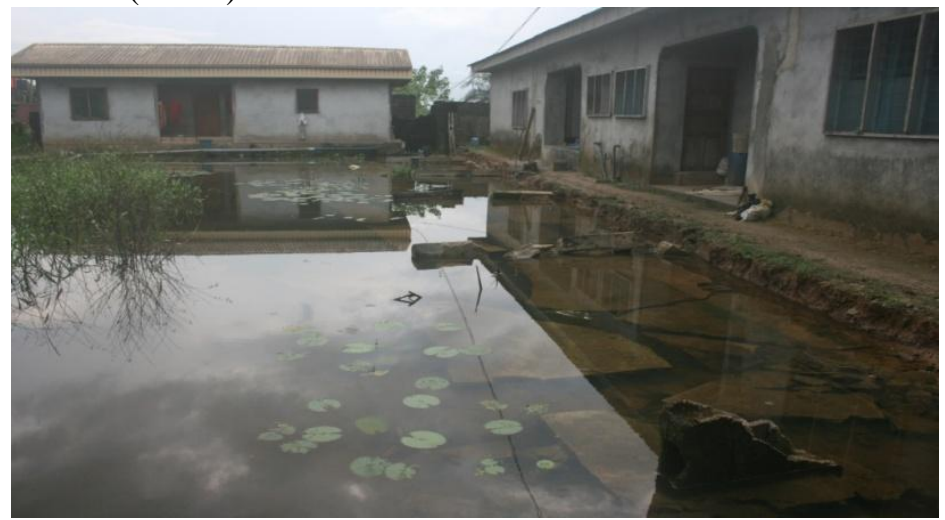

PLATE 2: A perennial layer of water formed in a compound as a result of uncontrolled urbanization in Old GRA (Golf Course zone), Port Harcourt metropolis 


\subsubsection{Poor drainage network}

The ranking of the causes of flooding shows that poor drainage network is the sixth and this was informed by $11.88 \%$ of the respondents in the study area (Table 1). Although some areas in Port Harcourt metropolis are provided with drainage facilities, they are either not enough in number and capacity or they are not properly interconnected (poor connectivity/network) to convey the generated surface run-off. This factor is among the major factors causing river floods downstream in Port Harcourt metropolis, because poor drainage network causes all the flood water from the different zones to reach the natural drains (e.g. Rivers and creeks) at the same times. When the storm waters reach these rivers and streams simultaneously, the run-off volume would exceed their local flow capacities causing river floods. This is evident mostly in Town and Amatagwolo Zones especially in Diobu, Lagos and Borokiri areas which make up the old Port Harcourt City.

There have been cases of poor connectivity of drainage facilities leading to run-off being trapped for sometime in some areas. Because run-off must be generated during periods of heavy rains, then there is need for it to be emptied into drains as fast as it is being generated. If this does not happen as a result of poor drainage network, the excess water would be trapped somewhere and forms a layer of water over land surfaces. This is common after periods of heavy rains in Port Harcourt metropolis.

\subsubsection{Flat Terrain}

$7.10 \%$ of the respondents indicated flat terrain to be the major cause of flooding and this factor was ranked the seventh (Table 1). Port Harcourt metropolis is generally low-lying; this increases the rate at which the area is being flooded. This is because excessive rainfall has always generated floods in areas with less pronounced slopes. Usually whenever it rains, infiltration takes place and whenever infiltration capacity has been attained, the excess water would flow overland down slope to the nearest natural channel through the available drainage and sewer facilities. If the quantity of water flowing into the channels exceeds the channel capacity, the adjoining areas would be flooded. This occurs in Port Harcourt metropolis because the excess water is evacuated at a rate that is slower (because of its topography) than when the slopes are pronounced. This factor exacerbates all the flood types in all the zones in Port Harcourt metropolis.

\subsubsection{Climate change}

Climate change as a factor responsible for flooding Port Harcourt metropolis was indicated by $4.48 \%$ of the respondents and was ranked the eighth (Table 1). Climate change has been noted to bring about variability in rainfall and also cause sea level to rise which eventually flood adjoining coasts. Climate change has been predicted to cause incessant and unprecedented flooding in most coastal cities of the world (IPCC, 2001; 2007). Though, the actual amount of flooding caused by climate change in Port Harcourt metropolis was not established, IPCC (2001:5) predicted that one of the key adverse effects of predicted changes in climate is a "widespread increase in the risk of flooding for many human settlements".

\subsubsection{Unplanned Development on Flood Plains}

From Table 1 above, $3.7 \%$ of the respondents mentioned this factor to be a cause of flooding in the study and it was ranked the ninth factor. Uncontrolled urbanization in Port Harcourt metropolis has led to unplanned development in the flood plains and urban population encroachment on marginal low-lying riverine lands or swamps. Rural-urban migration has increased the population of Port Harcourt over the years leading to erection of indiscriminate and illegal structure by residents in floodwater pathways, thereby obstructing the free flow of run-off and aggravating river floods in these areas.

The flood plains especially in Town, Amatagwolo, Mgbuosimiri and Rumuepirikom Zones which are drained by different rivers and creeks (Bonny and Okpokar Rivers, Elechi and Dockyard creeks) have been fully developed without necessary precautions taken to absorb the excess surface water which accumulate as a result of presence of impervious surfaces. This continuing unplanned development in flood-prone areas and building in the pathways of overland flow, increase the risk of flash flood and flooding of adjoining areas.

From Table 1 above, it could be deduced that apart from heavy rainfall (which is a meteorological factor and cannot be influenced), characteristic/qualities of the drainage system contribute to almost $50 \%$ of the factors influencing flooding in Port Harcourt metropolis. The combined percentage of absence of/ inadequate drainage facilities, blocked drainage and poor drainage network as major causes of flooding in Port Harcourt metropolis is $42.59 \%$.

Holding other factors constant, these 3 factors are significant as factors causing flooding in Port Harcourt metropolis.

\subsection{Classification of factors responsible for Flooding in Port Harcourt Metropolis}

Classifying these factors into groups could help in appreciating the combined contributions of some factors responsible for flooding in Port Harcourt metropolis. For example, inappropriate town 
planning/uncontrolled urbanization and unplanned flood plains development together gave us $15.89 \%$ which is only $0.15 \%$ above absence of inadequate drainage facilities as a singular factor responsible for flooding in Port Harcourt metropolis (Table 2).

From table 2 below, it could be observed that flooding in Port Harcourt metropolis is caused by human factors which represents more than $2 / 3$ of the total identified causes of flooding, that is, $72.83 \%$ of the total respondents ascertained this.

TABLE 2: Classification of identified factors contributing to flooding in Port Harcourt metropolis

\begin{tabular}{|c|c|c|c|c|}
\hline Factors & Meteorological factor & Topographical factors & Human factor & others \\
\hline & $\begin{array}{c}\text { Heavy } \\
\text { Rainfall } \\
(15.59 \%)\end{array}$ & - $(7.10 \%)$ Flat terrain & \begin{tabular}{ll} 
- & Absence of inadequate drainages \\
facilities $(15.74 \%)$ \\
Blocked drainage $(14.97 \%)$ \\
- & Impervious surfaces $(14.35 \%)$ \\
Inappropriate town & \multicolumn{1}{c}{ town } \\
planning/uncontrolled urbanization \\
$(12.19 \%)$
\end{tabular} & $\begin{array}{l}\text { Climate } \\
\text { Change } \\
(4.48 \%)\end{array}$ \\
\hline Total & $15.59 \%$ & $7.10 \%$ & $72.83 \%$ & $4.48 \%$ \\
\hline
\end{tabular}

Source: Field work, 2011

2.3 Principal Component Analysis (PCA) results of the causes of flooding in Port Harcourt Metropolis

PCA was run on the causal factors of flooding in Port Harcourt metropolis to determine the underlying dimensions, and four components were extracted (Table 3).

TABLE 3: Variance Rotated Component Matrix of causes of flooding in Port Harcourt Metropolis

\begin{tabular}{|c|c|c|c|c|}
\hline \multirow[t]{2}{*}{ Factors responsible for flooding } & \multicolumn{4}{|c|}{ Component } \\
\hline & $\mathrm{I}$ & II & III & IV \\
\hline Heavy rainfall & $.872 *$ & -.237 & -.132 & .032 \\
\hline Flat topography & -.070 & -.236 & -.257 & $.814^{*}$ \\
\hline Inappropriate town planning/uncontrolled urbanisation & -.011 & $-.936^{*}$ & -.120 & .205 \\
\hline Absence of/inadequate drainage facilities & .350 & $-.704 *$ & -.121 & .051 \\
\hline Climate change & .261 & -.059 & .296 & .000 \\
\hline Poor drainage network & -.413 & -.084 & $.738 *$ & -.127 \\
\hline Impervious surfaces & .156 & $.668^{*}$ & -.544 & -.338 \\
\hline Unplanned development on floodplains & -.058 & $.907 *$ & .164 & .151 \\
\hline Blocked drainage systems & -.021 & -.162 & $.917 *$ & .083 \\
\hline Eigen value & 2.39 & 2.23 & 1.74 & 1.13 \\
\hline Percentage of explained variance & 22.56 & 21.42 & 20.70 & 18.52 \\
\hline Cumulative $\%$ of explained variance & 22.56 & 43.98 & 64.68 & 83.20 \\
\hline
\end{tabular}

Extraction Method: Principal Component Analysis.

Rotation Method: Varimax with Kaiser Normalization

*The significant loadings exceeding $+/-0.60$

\subsubsection{Interpretation of the components}

From the results of the PCA above, only one variable (i.e. heavy rainfall) was picked as being significant under Component I. Thus, the first underlying dimension of causes of flooding in Port Harcourt is heavy rainfall. This component has an Eigen value of 2.39 and explains $22.56 \%$ of the factors responsible for flooding in Port Harcourt metropolis (Table 3). Inappropriate town planning, unplanned development on floodplains, absence of/inadequate drainage facilities and impervious surfaces are significant under Component II, thus, the second underlying dimension is unplanned urban development which has an Eigen value of 2.23 and explains $21.42 \%$ of the total variance. Two variables viz; blocked drainage and poor drainage network are significant under Component III, the third underlying dimension is therefore, poor drainage quality and this has an Eigen value of 1.74 , and explains $20.70 \%$ of the total variance while only flat topography was picked for Component IV and it has its underlying dimension as low-lying topography. The fourth component has an Eigen value of 1.13 and explains $18.52 \%$ of the total factors responsible for flooding in Port Harcourt (Table 3).

The PCA therefore has reduced our 9 factors responsible for flooding in Port Harcourt metropolis to 4 underlying dimensions which explain $83.20 \%$ of the variance in causes of flooding in the metropolis (Table 3 ). The four underlying dimensions, their relative contributions and cumulative percentages are summarized in Table 4 below. 
TABLE 4: The Relative Contribution of the Underlying Dimensions of causes of flooding in Port Harcourt Metropolis

\begin{tabular}{|c|l|l|l|}
\hline Component & Underlying Dimension & $\begin{array}{l}\text { Relative Contribution } \\
(\%)\end{array}$ & Cumulative Percentage \\
\hline I & Heavy rainfall & 22.56 & 22.56 \\
\hline II & Unplanned urban development & 21.42 & 43.98 \\
\hline III & Poor drainage quality & 20.70 & 64.68 \\
\hline IV & Low-lying topography & 18.52 & 83.20 \\
\hline
\end{tabular}

\section{Recommendations}

- The Master Plan of the Greater Port Harcourt City Development Plan (GPHCDP) should be implemented. The Government of Rivers State proposed a Greater Port Harcourt City Development Plan (GPCDP) in 2008 whose main purpose is the re-awakening of the Garden City (Port Harcourt) through water resources, waste water and storm water master planning (Rivers State Government, 2008). These according to the Consultants, Arcus Gibb would be achieved through:

i. Creating a system to convey and manage storm water in order to mitigate safety hazards and minimize property losses and disruptions due to heavy storm water run-off and flooding in Port Harcourt city.

ii. Control and manage increased storm water run-off due to local development.

iii. Maintain travel in public streets during storm event.

This shows that the Rivers State Government is much aware of the problem of flooding in Port Harcourt metropolis and it is set to prevent and mitigate its consequence.

- Instilling communal actions: Community participation in flood prevention, control and mitigation is very important. Residents in all the zones can form a Joint Task Force (in their various streets) to ensure that drainage facilities (gutters) are regularly cleaned up to allow the free flow of flood waters. A penalty must be imposed so that anyone who defaults must pay a fixed amount of money to ensure its full implementation. These Joint Task Forces can further be absorbed by the Local Government Authorities to help monitor and maintain clean drainage facilities in all the zones.

- Demolition of illegal structures: Structures that are built on the pathways of flood waters which their obstruct flow should be demolished. This would reduce the increased rate of uncontrolled urbanisation/urban creep and decongest Port Harcourt City.

- Sustainable Drainage Systems (SUDs): A sustainable drainage system aims to mimic as closely as possible the natural drainage of an urban area in order to minimise the impact of urban development on the flooding and pollution of waterways.

- Building of dry dams/levees: A dry dam is a dam constructed for the purpose of flood control. Dry dams typically contain no gates or turbines, and are intended to allow the channel to flow freely during normal conditions.

\section{Conclusion}

The research has identified nine factors as the major causes of flooding in the metropolis, and these are; absence of/ inadequate drainage facilities, heavy rainfall, blocked drainage systems, impervious surfaces, inappropriate town planning/ uncontrolled urbanization, poor drainage network, flat terrain, climate change and unplanned development on flood plains. The study revealed that, apart from heavy rainfall (which is a meteorological factor and cannot be influenced), characteristic/qualities of the drainage system contribute to almost 50\% of the factors influencing flooding in Port Harcourt metropolis. The combined percentage of absence of/ inadequate drainage facilities, blocked drainage and poor drainage network as major causes of flooding in Port Harcourt metropolis is $42.59 \%$, and more than $2 / 3$ of these factors are human-induced.

PCA was used to determine the underlying dimensions of the causal factors of flooding in Port Harcourt metropolis, and the study revealed four dimensions viz; heavy rainfall, unplanned urban development, poor drainage quality and low-lying topography which explained $83.20 \%$ of the total variance. This shows that flood is a natural phenomenon but human activities and interventions such as uncontrolled urbanization have aggravated flooding in the metropolis. Also, Rural-urban migration has increased the population of Port Harcourt over the years leading to erection of indiscriminate and illegal structure by residents in floodwater pathways, thereby obstructing the free flow of run-off and aggravating river floods in the metropolis.

With respect to the identified causal factors of flooding in the study area, implementation of the Greater Port Harcourt City Development Master Plan; instilling communal actions; demolition of illegal structures; sustainable drainage systems; and building of dry dams were recommended as measures that would curtail the perennial flooding problem experienced in Port Harcourt metropolis. 


\section{References}

[1]. Adeloye, A. and Rustum R. ( 2011):Lagos (Nigeria) flooding and influence of urban planning. Journal of Urban Design and Planning (ICE), Volume 164 (3), pp. $175-187$.

[2]. Akpoghomeh, O.S. (2001): Street Map of Port-Harcourt Metropolis and its Environs. Kraft's Books Ltd., University of Ibadan, Ibadan.

[3]. Askew, A. J. (1999): "Water in the International Decade for Natural Disaster Reduction" in Leavesley et al (eds.) Destructive Water: Water-caused Natural Disasters, their Abatement and Control. IAHS, Publication No. 239.

[4]. Ayoade, J.O. (1979): A note on the recent flood in Ibadan. Savanna 8(1), pp.62-65.

[5]. Ayoade, J.O and Akintola, F.O. (1980): "Public perception of flood hazard in two Nigerian cities. Environ Int 4:277-280

[6]. Etuonovbe, A.K. (2011): The Devastating Effect of flooding in Nigeria. Bridging the Gap between Cultures. FIG Working week 1822 May, Marrakech, Morocco.

[7]. Folorunsho, R. and Awosika, L. (2001): Flood Mitigation in Lagos, Nigeria Through Wise Management of Solid Waste: a case of Ikoyi and Victoria Islands; Nigerian, Paper presented at the UNESCO-CSI workshop, Maputo 19-23 November 2001.

[8]. Handmer, J., Penning-Rowsell, E. and Tapsell, S. (1999): "Flooding in a WarmerWorld: The View from Europe". In Downing, T.E., Olsthoorn, A.A. and Tol, R.S.J. (eds.), Climate, Change and Risk. Routledge, London.

[9]. Israel, G.D. (1992): "Sampling the Evidence of Extension Program Impact". Program Evaluation and Organisational Development, Institute of Food and Agricultural Sciences (IFAS), University of Florida. PEOD-5, October.

[10]. Intergovernmental Panel on Climate Change (2001): Climate Change 2001: Impacts, Adaptation, and Vulnerability, Summary for Policymakers. A Report of Working Group II of the IPCC, IPCC, Geneva.

[11]. Intergovernmental Panel on Climate Change (2007): "Appendix 1:Glossary". In: Climate Change 2007: Impacts, adaptation and vulnerability. Contribution of Working Group II to the Fourth Assessment Report of the International Panel on climate Change. Parry, M.L., Canziani, O.F., Palutikof, J.P., Van der Linden, P.J. and Hanson, C.E. (eds.). Cambridge University Press, Cambridge.

[12]. Jeb, D. N. and Aggarwal, S. P. (2008), "Flood inundation hazard modelling of the River Kaduna using remote sensing and geographic information systems", Journal of Applied Sciences Research, 4 (12), pages 1822 - 1833.

[13]. Mukhopadhyay, S. (2010): "A Geo-Environmental Assessment of Flood Dynamics in Lower Ajoy River Inducing Sand Splay Problem in Eastern India”. Ethiopian Journal of Environmental Studies and Management Vol.3(2)

[14]. National Population Commission (2006): “Census 2006" Final Reports, RiverState.

[15]. Ogba, C. O. and Utang B. P. (2008): Integrated Approach to Urban Flood Adaptation in the Niger Delta Coast of Nigeria. Integrating Generations, FIG Working Week, Stockholm, Sweden.

[16]. Okoduwa, A.I. (1999): An Application of GIS to Flood Prediction: A Case Study of Benin City, Nigeria. Unpublished B. Sc. Project, Department of Geography and Planning University of Benin, Nigeria.

[17]. Olaniran, O.J. (1983): Flood generating mechanisms at Ilorin, Nigeria. GeoJournal 7(3):271-277.

[18]. Ologunorisa, T.E. (2004): An Assessment of Flood Vulnerability Zones in the Niger Delta, Nigeria. International Journal of Environmental Studies, U. K. Vol. 61(1).

[19]. Ologunorisa, T.E. and Terso, T. (2006): The changing rainfall pattern and its implications for flood frequency in Makurdi, Northern Nigeria. Journal of Applied Sciences and Environ Management 10(3):97-102.

[20]. Olorunfemi, F.B. (2011): Managing flood disasters under a changing climate: lessons from Nigeria and South Africa. NISER Discussion Paper No.1. Paper presented at NISER Research Seminar Series, NISER, Ibadan on 3rd May.

[21]. Onokerhoraye, A. G. (1995): Urbanization and Environment in Nigeria: Implications for National Development. The Benin Social Science Series for Africa, Benin.

[22]. Oriola, E.O. (1994): "Strategies for combating urban flooding in a developing nation: A case study from Ondo, Nigeria." The Environmentalist, Volume 14(1), pp.57-62.

[23]. Orok, H.I. (2011): A GIS-Based Flood Risk Mapping of Kano City, Nigeria. Unpublished M.Sc thesis, School of Environmental Sciences, University of East Anglia, Norwich.

[24]. Parker, D.J. (1999): "Flood”, in Ingleton, J. (ed.), Natural Disaster Management, Tudor Rose, Leicester, pp.38-40.

[25]. Rivers State Government (2008): The Greater Port Harcourt City Development Master Plan: Water Resources, Wastewater and Storm water. Re-awakening the Garden City. ARCUS GIBB Engineering and Science, Vol. 3.

[26]. Stoltman, J.P., Lidstone, J. and Dechano, L.M. (2004): International Perspectives on Natural Disasters: Occurrence, Mitigation, and Consequences. Springer, New York.

[27]. WMO/GWP (Associated Programme on Flood Management) (2008): Urban Flood Risk Management- A Tool for Integrated Management Version 1.0.

[28]. Yamane, T. (1967): Statistics: An Introductory Analysis. Harper and Row, New York ( $2^{\text {nd }}$ edition). 